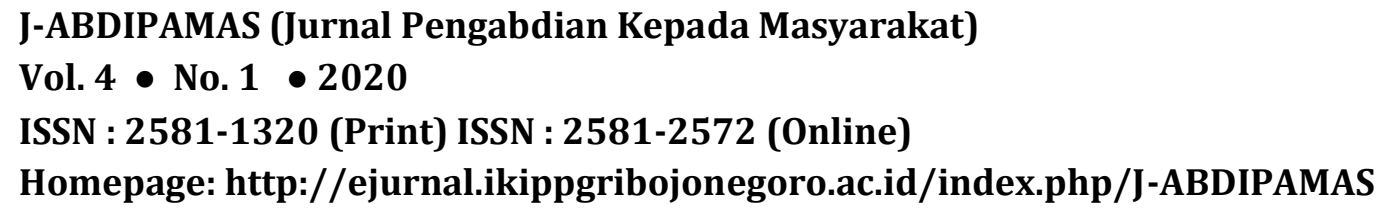

ISSN : 2581-1320 (Print) ISSN : 2581-2572 (Online)

Homepage: http://ejurnal.ikippgribojonegoro.ac.id/index.php/J-ABDIPAMAS

\title{
PENINGKATAN LITERASI KEUANGAN MELALUI INOVASI SI APIK BAGI UMK DESA TANJUNG RAYA KABUPATEN LAHAT
}

\author{
Yuliani ${ }^{1}$, Rasyid Hs Umrie ${ }^{2}$, Samadi W Bakar ${ }^{3}$ \\ ${ }^{1}$ Universitas Sriwijaya. Email: yulianisyapril@unsri.ac.id \\ 2 Universitas Sriwijaya. Email: rasyidhsu@gmail.com \\ 3 Universitas Sriwijaya. Email: samadiwbakar@yahoo.com
}

\begin{abstract}
Financial literacy is one of the keys to success for an entrepreneur. The classic problems that arise in Micro and Small Enterprises (MSEs) are the lack and difficulty of accessing capital in financial institutions, obstacles in preparing and recording financial reports, keeping the business growing and developing. This service aims to provide financial knowledge about increasing financial literacy and assisting people who have MSEs to conduct financial records and produce financial reports. This activities was implemented at Village Head's Office of Suka Merindu, Lahat Regency. The method of delivering material through counseling in the form of education about saving, investment, insurance. The activity continued with assistance in making financial reports with the Android Si Apik technology innovations issued by Bank Indonesia. The number of target audiences is 40 MSEs. The results of this activities is MSEs know the types of savings, investment and the importance of insurance protection. MSEs experienced difficulties when using Si Apik because the recording of single bookkeeping was not yet owned. This activity is expected by the general public and MSEs to be able to manage household finances and business so that financial prosperity is achieved in the future.
\end{abstract}

Keywords: Saving, Investment, Insurance, Financial Literacy, Si Apik

\begin{abstract}
ABSTRAK
Literasi keuangan merupakan salah satu kunci keberhasilan bagi seorang entrepreneur. Permasalahan klasik yang muncul pada Usaha Mikro dan Kecil (UMK) adalah kurangnya dan kesulitan mengakses modal pada lembaga keuangan, hambatan dalam menyusun dan mencatat laporan keuangan, promosi penjualan dan menjaga agar usaha terus tumbuh dan berkembang. Pengabdian ini bertujuan untuk memberikan pengetahuan keuangan tentang literasi keuangan dan mendampingi masyarakat yang memiliki UMK dalam melakukan pencatatan keuangan hingga menghasilkan laporan keuangan. Kegiatan ini dilaksanakan di Kantor Kepala Desa Suka Merindu Kabupaten Lahat. Metode penyampaian materi melalui penyuluhan berupa edukasi tentang menabung, investasi, asuransi. Kegiatan dilanjutkan dengan pendampingan membuat laporan keuangan dengan metode inovasi Si Apik berbasis Android yang dikeluarkan oleh Bank Indonesia. Jumlah khalayak sasaran adalah 40 UMK. Hasil kegiatan ini adalah UMK mengetahui jenis tabungan, investasi dan pentingnya perlindungan asuransi. UMK mangalami kesulitan saat menggunakan Si Apik karena pencatatan pembukuan tunggal belum dimiliki. Kegiatan ini diharapkan masyarakat pada umumnya dan UMK mampu mengelola keuangan rumah tangga dan usahanya sehingga tercapai kesejahteraan dalam keuangan di masa mendatang.
\end{abstract}

Kata Kunci: Menabung, Investasi, Asuransi, Literasi Keuangan, Si Apik 


\section{PENDAHULUAN}

Desa Tanjung Raya merupakan salah satu desa yang masuk dalam kecamatan Sukamerindu. Kecamatan Sukamerindu memiliki 10 desa yaitu Gunung Liwat, Guru Agung, Kapitan, Karang Caya, Pagar Kaya, Rambai Kaca, Sukamerindu, Sukaraja, Tanjung Agung dan Tanjung Raya. Secara geografis Kecamatan Sukamerindu memiliki luas $55.230 \mathrm{~km}^{2}$ dan jumlah penduduk 6.867 jiwa (3.494 adalah laki-laki dan 3.373 adalah perempuan) dengan kepadatan penduduk per $\mathrm{km}^{2}$ sebanyak 124,3 orang (BPS, 2018). Perkembangan desa dengan lahan yang subur membuat masyarakat tidak mengalami kendala dalam hal keuangan karena kehidupan para petani dan industri cukup baik.

Hasil pengamatan awal yang dilakukan oleh tim pengabdian pada Bulan Januari 2019 dengan bertemu Kepala Desa dan tiga orang ibu dan dua orang bapak yang memiliki usaha warung sembako, petani kopi dan kerajinan tangan. Hasil observasi pada waktu itu adanya masalah dalam pengelolaan keuangan terutama sulitnya membagi atau membedakan uang untuk keperluan rumah tangga dan untuk keberlangsungan usaha yang mereka miliki. Catatan penting dari Kepala Desa ungkapkan terkait dengan perilaku konsumtif. Perilaku konsumtif masyarakat membuat Kepala Desa cukup terkejut sehingga edukasi tentang pengelolaan keuangan bagi rumah tangga sangat penting mengingat kehidupan masyarakat menjadi tidak seimbang. Begitu juga dengan masyarakat yang memiliki Usaha Mikro dan Kecil (UMK) akan pentingnya mengelola keuangan dengan bijak. Beberapa kendala yang menjadi masalah klasik dalam UMK dan terjadi pada masyarakat di Desa Tanjung Raya adalah bingung mengelola usaha, belum memahami cara membuat laporan keuangan atas usaha yang dijalankan, kekurangan modal dan bingung dalam hal memasarkan hasil produksi.

Kondisi ini memicu pentingnya untuk memberikan edukasi tentang pengelolaan keuangan yaitu pengetahuan keuangan dengan literasi keuangan dan penting untuk melakukan pencatatan atas penerimaan dan pengeluaran kas untuk UMK. Literasi keuangan merupakan suatu pengetahuan, keterampilan dan keyakinan yang akan mempengaruhi sikap dan perilaku seseorang untuk meningkatkan kualitas pengambilan keputusan dan pengelolaan keuangan dalam rangka mencapai kesejahteraan (OJK, 2017). Seiring dengan pentingnya literasi keuangan maka Otoritas Jasa Keuangan (OJK) mempublikasikan indeks literasi keuangan masyarakat Indonesia yang tertuang pada Strategi Nasional Literasi Keuangan Indonesia (SNLKI) dimana indeks tersebut cukup mengejutkan bahwa indeks literasi keuangan masyarakat Tahun 2013 yaitu 21,8\% dan hasil survey Tahun 2016 meningkat menjadi 29,7\% artinya setiap 100 orang hanya betul-betul yang well literate hanya 22 orang (2016) dan 30 orang (2016).

Indeks literasi yang masih jauh tertinggal dari negara-negara lainnya maka Pemerintah Indonesia mentargetkan untuk tahun ini 2019 meningkat menjadi 75\%. Memang target ini cukup tinggi mengingat perilaku masyarakat Indonesia yang cenderung konsumtif. Hal ini dapat dilihat pada data perbandingan antara jumlah rekening, total simpanan dan pertumbuhan jumlah uang beredar (OJK, 2017). Total simpanan dilakukan pada perbankan. Bank merupakan lembaga keuangan yang bergerak di bidang keuangan meliputi saving, lending dan services (Yuliani, 2016). 
Kecenderungan data perbandingan tersebut mengindikasikan bahwa memang masyarakat Indonesia yang well literate masih tergolong rendah.

Berdasarkan uraian diatas maka tujuan pengabdian ini meliputi dua hal utama yaitu edukasi literasi keuangan bagi masyarakat di Desa Tanjug Raya Kecamatan Sukamerindu Kabupaten Lahat dan membimbing para UMK dalam menyusun laporan sumber dan penggunaan dana dengan inovasi Si Apik dari Bank Indonesia. Si Apik merupakan aplikasi berbasis Android yang dikeluarkan oleh Bank Indonesia untuk digunakan dalam pencatatan transaksi keuangan bagi UMK. Inovasi Si Apik sangat simple dan mudah digunakan sehingga UMK pada akhirnya memiliki laporan keuangan atas usaha yang dijalankan. Aplikasi inovasi Si Apik dapat digunakan untuk usaha perorangan dan berkelompok. Penggunaan Si Apik memberikan kemudahan dalam hal pengelolaan usaha sehingga jika usaha memerlukan pendanaan eksternal maka sangat mudah untuk melampirkan kondisi keuangan usaha.

\section{METODE PELAKSANAAN}

Adapun metode pelaksanaan kegiatan pengabdian ini adalah pendampingan. Metode ini telah dilakukan oleh beberapa tim pengabdian di Indonesia seperti (Prajarini \& Rahardjo, 2018; Widianto et al, 2019). Kegiatan ini dimulai dari memberikan edukasi tentang literasi keuangan untuk masyarakat termasuk juga materi tentang perencanaan keuangan rumah tangga. Metode pendampingan dalam mengelola keuangan usaha. Kegiatan ini ditujukan kepada masyarakat di Tanjung Raya yang memiliki usaha yang masih kategori UMK. Kategori mikro adalah entitas usaha dimana jumlah tenaga kerja adalah 1-4 orang. Kategori kecil dan 5-19 orang untuk menengah memiliki jumlah karyawan 20-99 orang (BPS, 2018). Sasaran kegiatan adalah kelompok UMK di Desa Tanjung Raya Kecamatan Suka Merindu dan sudah memiliki usaha tetapi karena keterbatasan dalam mengelola keuangan dalam hal menyusun laporan keuangan, laporan sumber dan penggunaan dana sehingga perlu dibantu oleh tim pengabdian untuk didampingi. Metode kegiatan pendampingan berupa pendampingan manajemen khususnya manajemen keuangan dalam hal pengelolaan dana baik sumber dana dan penggunaan dana. Tahapan kegiatan pengabdian meliputi identifikasi masalah, penetapan masalah dan memberikan solusi permasalahan, memberikan edukasi tentang literasi keuangan baik untuk individu, rumah tangga dan pelaku usaha, melaksanakan kegiatan pengabdian, pendampingan kegiatan, evaluasi.

Tahapan pertama yaitu identifikasi masalah yaitu dengan wawancara dan observasi. Sebelum proposal pengabdian dibuat dua orang tim anggota pengabdian sudah berkunjung ke Desa Tanjung Raya Kecamatan Sukamerindu untuk mengidentifikasi permasalahan yang ada di desa tersebut. Observasi dilakukan pada Bulan Januari 2019. Tahapan kedua adalah menyusun proposal dengan menetapkan masalah yang akan diberikan solusi untuk desa tersebut. Kegiatan pengabdian diberikan materi edukasi tentang literasi keuangan yang akan disampaikan oleh ketua tim pengabdian ini yaitu ibu Dr Yuliani, SE., MM., CFP, QWP, AEPP dimana kompetensi ketua pengabdian adalah sangat sesuai dengan topik pengabdian ini. Selanjutnya ketua pengabdian akan dibantu oleh dua anggota tim dan mahasiswa. Dua anggota tim adalah 
dosen yang memang bidang keilmuwan Manajemen Keuangan yaitu Bapak Drs. H. Rasyid Hs Umrie, MBA dan Bapak Drs. H. Samadi W Bakar, SU. Adapun jumlah mahasiswa yang terlibat sebanyak 2 orang yang konsentrasi Manajemen Keuangan.

Tahapan berikutnya adalah pendampingan. Kegiatan ini akan dilakukan secara intensif dengan memperkenalkan aplikasi inovasi Si Apik dalam mencatat setiap transaksi penerimaan dan pengeluaran kas untuk pelaku usaha. Ukuran keberhasilan pendampingan ini adalah pelaku usaha mampu menggunakan aplikasi inovasi Si Apik dan memiliki laporan keuangan.

\section{HASIL DAN PEMBAHASAN}

Kegiatan pengabdian diawali dengan pembukaan oleh Kepala Desa Tanjung Raya yaitu Bapak Nopriandi. Pelaksanaan kegiatan bertempat di Kantor Kepala Desa lantai 2 Desa Tanjung Raya. Setelah dibuka oleh kepala desa teknis acara dibagi menjadi 3 sesi. Pertama, pembukaan, kedua paparan materi dan ketiga diskusi dan penutupan dilanjutkan dengan foto bersama. Kegiatan pertama, pembukaan. Acara ini diawali dengan pemutaran video literasi keuangan untuk masyarakat. Setelah dibuka dilakukan pertanyaan ringan tentang pengelolaan keuangan yang telah dilakukan oleh peserta pengabdian. Hasil dari pertanyaan pembuka 90\% peserta tidak memiliki rekening tabungan. Berdasarkan pertanyaan ringan ini maka kami memberikan materi tentang merencanakan keuangan. Kegiatan kedua, penyampaian materi dimulai dengan memberikan pengertian tentang literasi keuangan dan pentingnya merencanakan keuangan dengan cerdas. Terdapat tiga hal penting terkait dengan literasi keuangan yaitu menabung, investasi dan asuransi.

Kegiatan menabung merupakan investasi yang bersifat rutin dilakukan. Kegiatan menabung dilakukan di awal bulan bagi pegawai atau saat mendapatkan uang langsung disisihkan untuk menabung. Beberapa pilihan kegiatan menabung yaitu di perbankan, pegadaian dan di pasar modal. Bagi masyarakat desa kegiatan menabung dapat dilakukan dengan bank dan pegadaian karena dua lembaga ini mudah ditemukan di desa ataupun di kecamatan. Bank memiliki tiga produk untuk kegiatan menabung yaitu giro, tabungan dan deposito. Perbedaan ketiganya terletak pada jumlah setoran awal, jangka waktu dan sarana pengambilan uang. Untuk masyarakat dapat memilih salah satu yang paling fleksibel yaitu produk tabungan (saving). Saat ini cukup banyak variasi produk tabungan tersedia di perbankan. Selain dari produk bank ada juga lembaga yang menerima tabungan berupa emas yaitu di pegadaian. Masyarakat boleh membawa uang kemudian akan dikonversi menjadi emas.

Investasi diartikan pengalokasian dana yang diharapkan untuk masa mendatang mendapatkan keuntungan (return). Beberapa bentuk investasi yang paling mudah ditemukan di lokasi pengabdian adalah sawah dan kebun. Bentuk investasi ini tergolong investasi produktif dengan syarat sawah dan kebun ditanami pohon yang menghasilkan pendapatan misalnya kopi, karet, kebun rambutan, kebun durian dan sebagainya. Atas hasil dari panen tanaman tersebut maka dapat disisihkan untuk tabungan. Masyarakat di Desa Tanjung Raya dominan bertani kopi. Saat masa tunggu penjualan kopi cukup 
lama sehingga dengan dikelola keuangan masyarakat tidak mengalami kesulitan untuk bertahan hidup dalam memenuhi kebutuhan sehari-hari.

Filosofi asuransi adalah proteksi atau melindungi dari risiko. Jenis risiko ada dua yaitu risiko sistematis dan tidak sistematis. Asuransi akan melindungi jiwa, kesehatan ataupun harta. Masyarakat dapa memilih premi yang relatif kecil untuk membuka polis asuransi sesuai dengan tujuan. Hal yang paling penting dalam asuransi agar setiap pencari nafkah memiliki satu polis asuransi minimal asuransi jiwa. Saat ini produk asuransi dari perusahaan asuransi cukup beragam sehingga masyarakat memiliki alternatif dalam memilih produk asuransi yang penting.

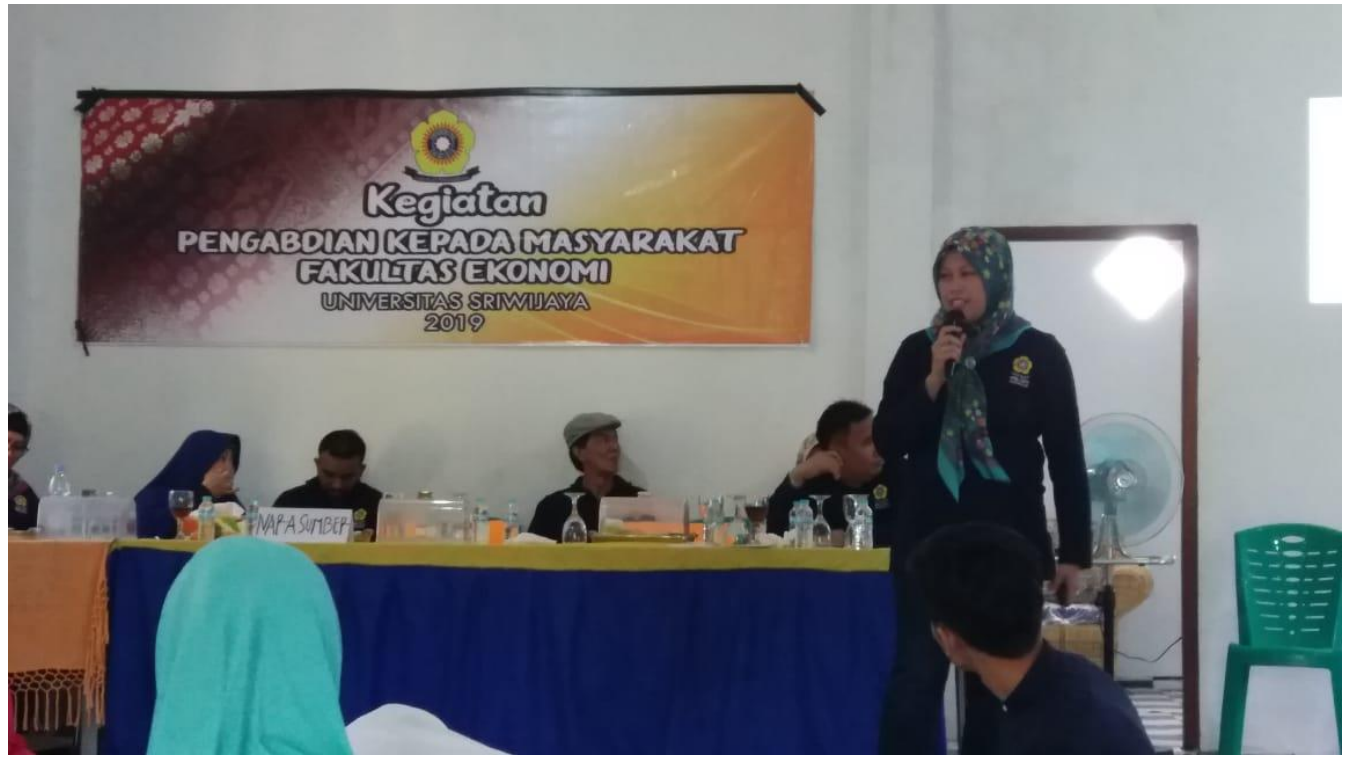

Gambar 1. Pemberian Materi Literasi Keuangan

\section{Pengenalan Si Apik}

Masyarakat Desa Tanjung Raya Kecamatan Suka Merindu sehari-hari sebagai petani kopi dan berdagang. Ada beberapa penghasilan bersumber dari toko dan menjual kopi. Kendala yang ada peserta pengabdian masih belum mampu membedakan antara uang yang dipakai untuk usaha dan uang untuk rumah tangga. Terkadang peserta tidak pernah mencatat pembukuan karena beberapa hal sebagai alasan seperti tidak paham, susah dan kurang penting. Padahal salah satu kendala UMK dalam permodalan. Terkadang modal yang sudah ada tidak ada pembukuan yang baik akan menimbulkan kesulitan untuk mengetahui informasi keuangan usaha.

Sebagai upaya mengatasi kurang informasi dalam menyusun, mencatat pengeluaran dan pemasukan uang bagi UMK di Desa Tanjung Raya maka diperlukan suatu ilmu pengetahuan yang bersifat praktis dalam penggunaan aplikasi dan sesuai dengan era digital saat ini. Bank Indonesia telah melauncing aplikasi berbasis teknologi yang dapat digunakan untuk mencata setiap transaksi usaha baik penerimaan maupun pengeluaran kas atau uang. Aplikasi ini disebut dengan Si Apik (Sistem Aplikasi Pencatatan Informasi Keuangan). Si Apik dirancang untuk mencatat transaksi keuangan bagi UMK. Si Apik mampu menghasilkan laporan keuangan serta menyajikan hasil analisis keuangan yang mencerminkan kinerja keuangan UMK. 
Adapun tujuan dari Si Apik meliput tiga hal yaitu sebagai standar menyusun laporan keuangan untuk UMK, menjadi alat bantu dalam menyusun laporan keuangan serta membantu kreditur dalam menganalisis kemampuan UMK saat mengajukan kredit atau pembiayaan. Adapun fitur-fitur yang terdapat dalam aplikasi Si Apik adalah:

1. Pengisian periode awal transaksi

2. Penjualan hasil produksi tunai

3. Pembelian bahan material tunai

4. Biaya tenaga kerja

5. Laporan history transaksi

6. Laporan neraca

7. Laporan laba rugi dan salod laba

8. Backup database

9. Restore database.

Beberapa tahapan dalam menggunakan Si Apik sebagai berikut (LAMPIRAN):

1. Download dari play store kemudian unduh aplikasi Si Apik

2. Setelah diunduh buka aplikasi Si Apik dan buat akun pengguna baru dan memilih jenis usaha. Selanjutnya pengisian data usaha.

3. Setelah selesai pengisian data usaha kemudian isi periode awal transaksi.

4. Melanjutkan dengan setting saldo awal dengan cara pilih "Menu Transaksi $\rightarrow$ "Master data $\rightarrow$ 'Master saldo awal. Untuk pengisian saldo awal tersedia pilihan jenis saldo awal lalu isikan jumlah nominal saldo awal.

5. Masukkan data master untuk pelanggan, pemasok dan bahan material yang dibeli.

6. Setiap pembelian bahan secara tunai diisikan

7. Setiap pengeluaran dimasukkan

8. Setiap penjualan usaha secara tunai diinput

9. Jika ada sumber dana eksternal berupa hutang maka diinput

10. Setelah selesai pengisian data-data pada tahap 4-9 maka laporan keuangan berupa neraca dapat langsung ditampilkan.

\section{Selesai}

Setelah pemberian materi literasi keuangan dan pengenalan Si Apik beberapa pertanyaan muncul dari peserta. Pertanyaan mendasar seperti tidak memiliki rekening tabungan karena belum paham cara menabung di bank, untuk pinjaman dana lebih sering pinjam di koperasi atau di desa tersebut yang sering dijadikan tempat pinjam. Masyarakat sebagai pelaku UMK belum tertib administrasi keuangan pencatatan keuangan. Pengenalan Si Apik memberikan pengetahuan baru bagi UMK tentang pencatatan keuangan berbasis aplikasi. 


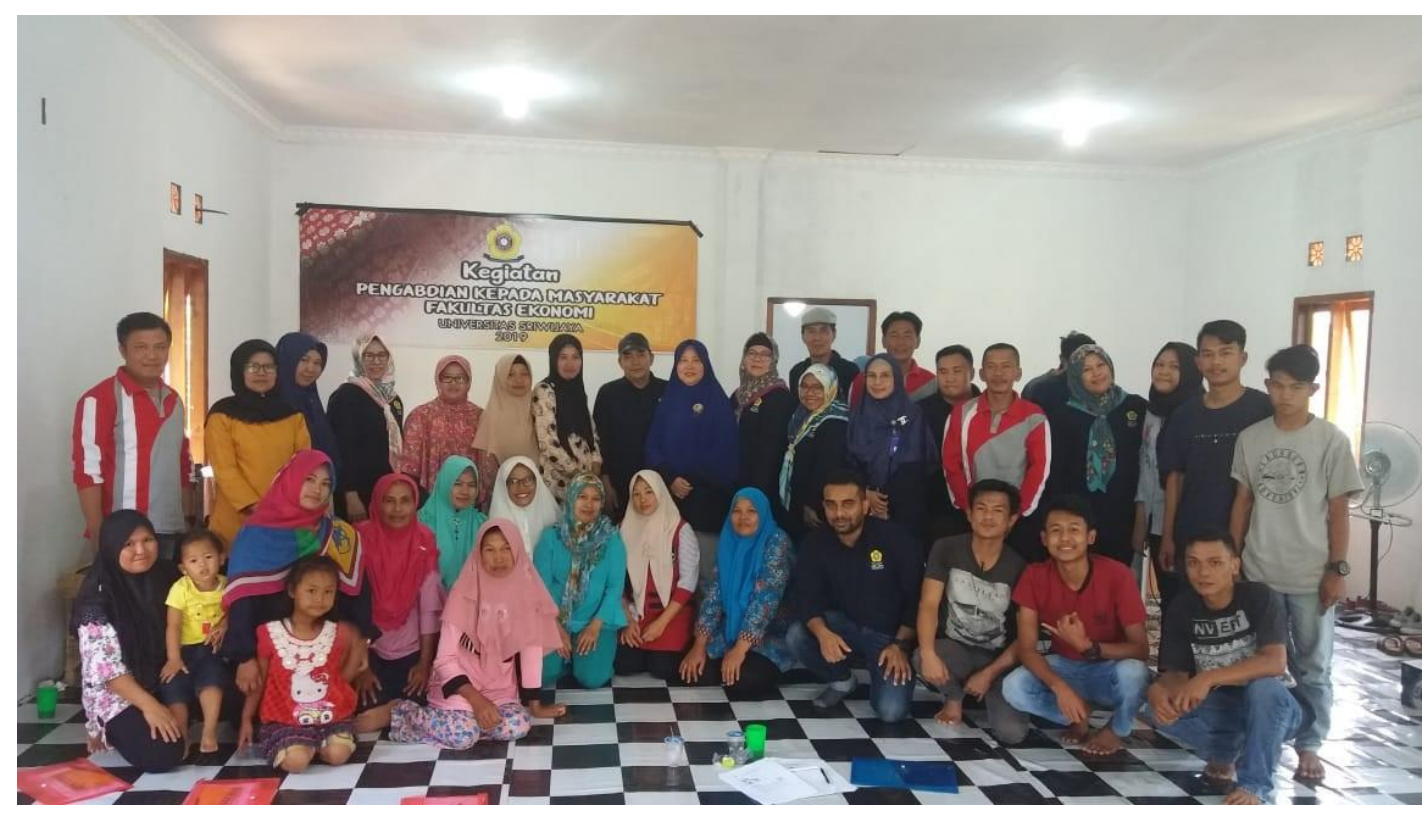

Gambar 2. Foto bersama peserta pengabdian

\section{SIMPULAN}

Berdasarkan pembahasan diatas beberapa kesimpulan dari kegiatan pengabdian masyarakat di Desa Tanjung Raya Kecamatan Suka Merindu sebagai berikut:

1. Khalayak sasaran belum memahami tentang kegiatan menabung, investasi dan asuransi. Untuk menabung lebih banyak disimpan di rumah. Produk bank walaupun tersedia tapi masyarakat belum begitu paham dengan prosedur dan syarat-syarat untuk membuka rekening simpanan.

2. Kegiatan investasi lebih banyak pada kebun kopi. Usaha seperti toko, berdagang hanya sebatas pemenuhan kebutuhan hidup sehari-hari. Belum optimal dalam menghasilkan produk kopi yang bervariasi sehingga menghasilkan nilai tambah hasil penjualan kopi yang lebih besar.

3. Masyarakat belum memahami asuransi dan betul-betul tidak paham fungsi dan kegunaan produk asuransi.

4. Pelaku UMK di desa sudah digital dengan industri 4.0 namun untuk melakukan pencatatan atas pembukuan sederhana berbasis teknologi masih hal baru sehingga diperlukan pendampingan sebagai agenda pengabdian yang akan datang.

\section{UCAPAN TERIMA KASIH}

Tim pengabdian masyarakat mengucapkan terima kasih kepada Lembaga Penelitian dan Pengabdian Masyarakat Universitas Sriwijaya yang telah mendanai kegiatan ini. Terima kasih juga kepada para mahasiswa, pak kades dan tim lainnya yang telah mendukung dan membantu sebelum dan saat kegiatan pengabdian dilaksanakan sehingga dapat menambah wawasan masyarakat tentang literasi keuangan dan pengenalan Si Apik untuk memudahkan mencatat pembukuan berbasis teknologi. 


\section{DAFTAR RUJUKAN}

BPS. (2018). Kabupaten Lahat Dalam Angka 2018. Katalog BPS 1102001.1604. Lahat: Badan Pusat Statistik Kabupaten Lahat.

OJK. (2017). Strategi Nasional Literasi Keuangan Indonesia (Revisit 2017). SNLKI.

Prajarini, D., \& Rahardjo, S. T. (2018). Pendampingan Pemanfaatan TIK untuk Administrasi Data UMKM Desa Wisata \& Kerajinan Gamplong. Abdimas Dewantara, 1(1), 65-76.

Widianto, A., Noermansyah, A. L., \& Kamal, B. (2019). Pelatihan Pencatatan Transaksi Keuangan Menggunakan Aplikasi "Si-Apik" di SMA Negeri 3 Brebes. Jurnal Abdimas PHB, 2(1), 34-38.

Yuliani. (2016). Manajemen Lembaga Keuangan. Palembang: Citra Books. 


\section{Lampiran}
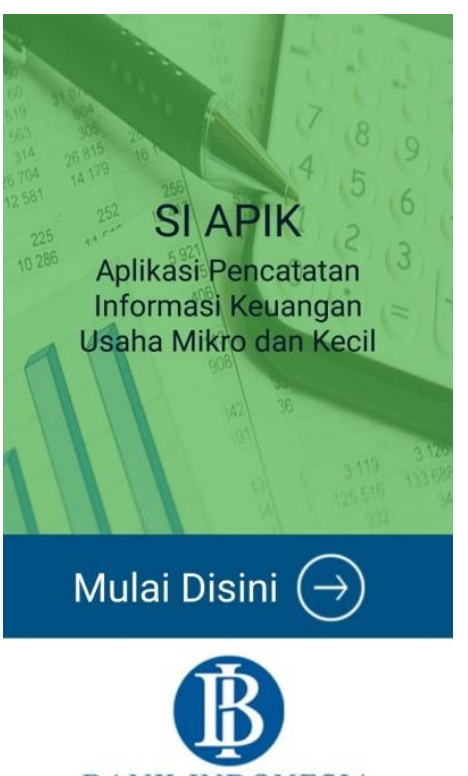

BANK INDONESIA sebelum menggunakan aplikasi ini

\section{Klik untuk penjelasan lengkap..}
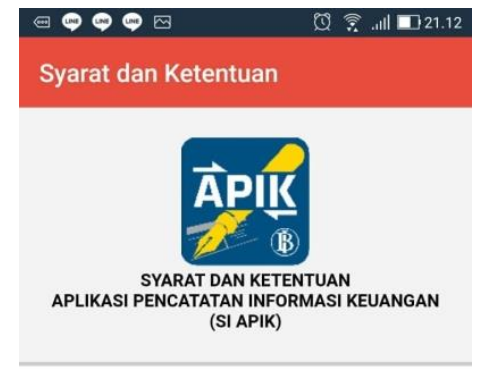

Harap baca Syarat dan Ketentuan ini dengan seksama

Dengan mengklik dan menerima syarat dan ketentuan yang anda setujui bahwa anda telah membaca, memahami, mengakui dan menyetujui syarat dan ketentuan ini, maka anda dapat mengakses dan

\section{(1D) BANK INDONESIA}

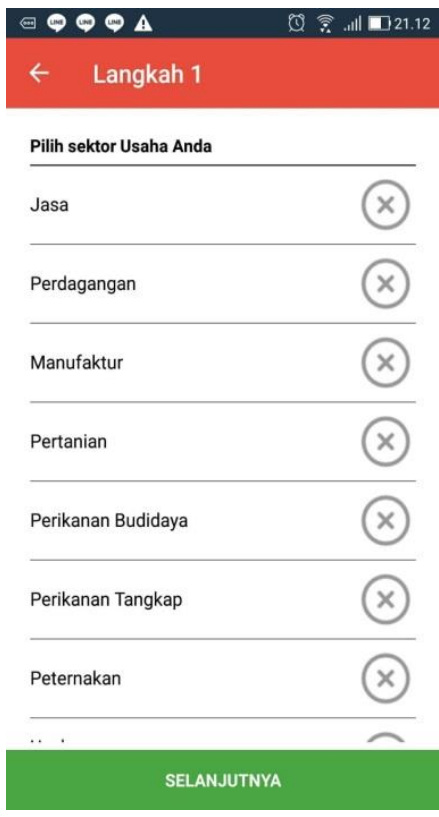

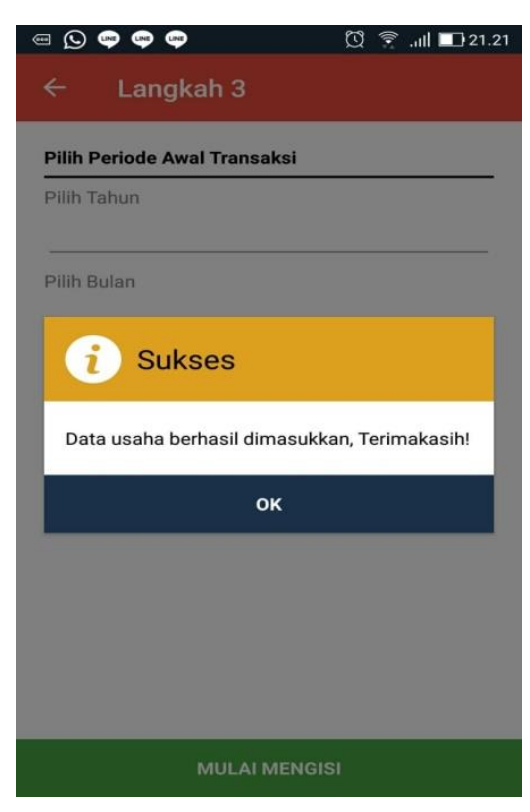

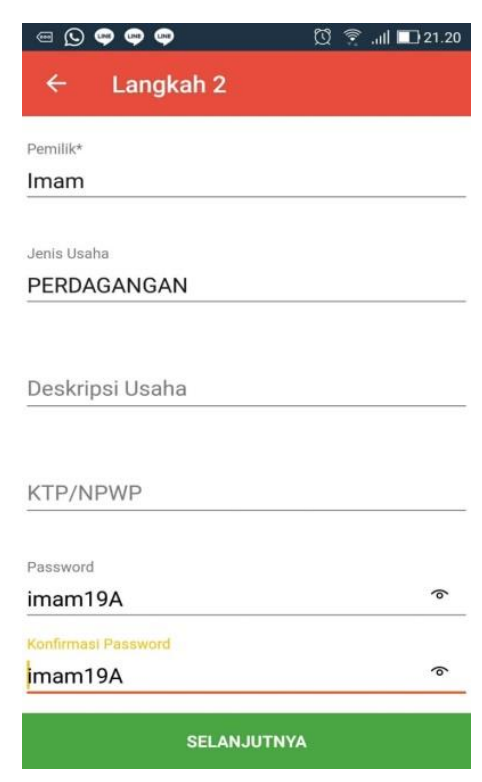

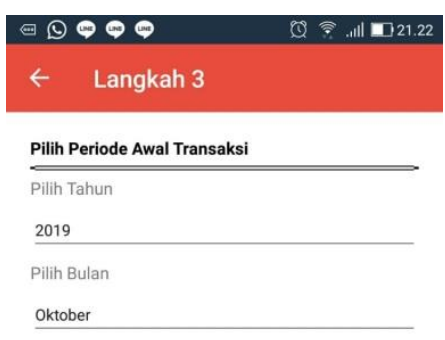


126 J-Abdipamas, Vol. 4, No. 1, April 2020 